\title{
Promise and Disillusionment in the Shape of a Woman: Conquistadors in Florida and New France, A Comparative Perspective
}

\author{
Daniel Murphree \\ University of Central Florida, FL, USA \\ Daniel.Murphree@ucf.edu
}

\begin{abstract}
The purpose of this study is to provide greater insight into the power of native women as understood by sixteenth century North American conquistadors by juxtaposing two analogous but geographically distinct settings. Depictions of women in New France by Jacques Cartier, Samuel Champlain and their followers in the northern borderlands of North America are compared to those depictions made by Hernando de Soto, Pedro Menendez de Avilés and their contemporaries during the same general period in the southern borderlands (Florida). The accounts of these figures, who came from varied backgrounds and promoted differing world views, provide evidence for the earliest foundations of the "imperial gaze" in reference to distant poles along North America's eastern seaboard. They also demonstrate the key role that native women played in orchestrating intercultural encounters with conquistadors during the sixteenth century.
\end{abstract}

\section{Keywords}

Native Americans - conquistadors - women - exploration - encounters - borderlands comparative

In late June or early July of 1603 , Samuel de Champlain noted that the Sauvages he encountered on his exploration of what would become New France informed him of a nearby "river that goes to the coast of Florida". ${ }^{1}$ Referring to

1 "Riviere qui va render à la coste de la Floride", in eds. Conrad E. Heidenreich and K. Janet Ritch, Samuel de Champlain before 1604: Des Sauvages and Other Documents Related to the Period (Toronto: McGill-Queen's University Press, 2010), 312-313. 
today's Hudson River, these Innu (Montagnais) Indians provided accurate information from the French point of view; many Europeans considered the entire Atlantic coast of North America to be part of Florida during the sixteenth and early seventeenth centuries. ${ }^{2}$ But Champlain and his fellow explorers in New France and their Spanish counterparts in the Florida peninsula to the distant south made few other connections between the regions. Scholars of colonial North America have followed suit. French colonization efforts in the north and Spanish colonization efforts in the south have generally been treated as largely separate endeavors with few parallels, especially regarding relationships with native peoples. Differing in strategies, techniques, motivations, and capabilities, French and Spanish men in both regions seemingly shared few similarities in how they dealt with Native American men. ${ }^{3}$

But what about European men and Native American women? Intellectually marginalized by the conquistadors ${ }^{4}$ themselves four hundred years ago and only recently studied at length by scholars of the regions in modern times,

2 According to Laurier Turgeon, "For the French, the 'Florida coast' covered a vast territory extending from the Florida peninsula ... to the northeastern part of the continent". Consequently, sixteenth-century French map makers and fishermen commonly referred to the present day New England-New Foundland coastline as "coste de la Floride". See Laurier Turgeon, "The French in New England before Champlain", in eds. Raymonde Litalien and Denis Vaugeois, Champlain: The Birth of French America, trans. Käthe Roth (Toronto: McGillQueen's University Press, 2004), 102.

3 See Colin G. Calloway, "Neither White Nor Red: White Renegades on the American Indian Frontier", Western Historical Quarterly 17 (1986), 46; W.J. Eccles, France in America (East Lansing: Michigan State University, 1990), 41; John M. Faragher, “More Motley than Mackinaw': From Ethnic Mixing to Ethnic Cleansing on the Frontier of the Lower Missouri, 1783-1833", in eds. Andrew R.L. Cayton and Fredrika J. Teute, Contact Points: American Frontiers from the Mohawk Valley to the Mississippi, 1750-1830 (Chapel Hill: University of North Carolina Press, 1998), 305; Richard White, The Middle Ground: Indians, Empires, and Republics in the Great Lakes Region, 1650-1815 (New York: Cambridge University Press, 1991), 341-342. Also see Digital History: Using New Technologies to Enhance Teaching and Research, "Overview of the Colonial Era", http://www.digitalhistory.uh.edu/era.cfm?eraID=2\&smtid=1 (accessed December 12, 2013).

4 The term conquistador is used in this work to reflect the shared perspectives that transcended Spanish and French explorers in reference to native women they encountered, regardless of the tactics they employed. In this sense, the mindsets of both the Spanish and French in this study served to "conquer" the reality of native women's lives, perhaps not through violence or law, but through marginalization of their capacities and autonomy. For a similar interpretation related to Spanish and English religious mindsets in the Americas, see Jorge Cañizares-Esguerra, Puritan Conquistadors: Iberianizing the Atlantic, 1550-1700 (Stanford, CA: Stanford University Press, 2006). 
indigenous women's interactions with European visitors to North America's Atlantic coast provide more connections than previously believed. While much about European activities in New France and Florida differed, surviving accounts from the sixteenth century, constructed by both Europeans and natives, provide an alternative picture in relation to Indian women. Evidence is fragmentary and parallels are inconsistent. Not all European explorers in these regions during this period addressed their encounters with native women, and in many cases, explorers said nothing in writing about female Indians at all. ${ }^{5}$ But early encounters in both regions provide glimpses of common behaviors previously overlooked. Stated another way, Spanish understandings of native women in Florida and French understandings of native women in New France provide connections at least as substantive as mapmakers' generalizations. To paraphrase Philip Morgan in reference to comparing black cultures in the eighteenth-century North American Chesapeake and "Lowcountry" regions, while Spanish and French understandings of native women may look "different in the light of the other ... our understanding of each is enlarged by knowledge of the other". ${ }^{6}$

Indeed, native women, or more specifically, perceptions of native women, both encouraged and disillusioned Spanish and French conquistadors in sixteenth-century New France and Florida. Rarely the focus of explorers' accounts, female Indians surfaced periodically in explorer chronicles as harbingers of success and failure in the lands coveted by Spain and France. How these impressions emerged and the parallels between them are still largely unexamined. Though recent scholarship on women and colonization in North America has explored French and Spanish understandings and depictions of women at length, most works have addressed interactions during the seventeenth and

5 Men from Spain or France typically did not devote much space in their writings to describing or evaluating the female natives they observed in North America's east coast hinterlands during the sixteenth century (or long sixteenth century when Champlain's early voyages to France are considered). The European accounts examined in this work therefore represent only those sixteenth-century Spanish visitors to what would eventually be labeled Florida and French visitors to what soon became known to Europeans as France who provided written commentary on the native women they encountered. Moreover, I have not addressed sixteenth-century French visitors to Florida primarily affiliated with the Fort Caroline settlement near present-day Jacksonville, Florida, here though readers interested in their viewpoints on native women should consult: Daniel S. Murphree, "Gendering the Borderlands: Conquistadors, Women, and Colonialism in Sixteenth-Century Florida", Sixteenth Century Journal 43, no. 1 (2012): 47-69.

6 Philip D. Morgan, Slave Counterpoint: Black Culture in the Eighteenth-Century Chesapeake \& Lowcountry (Chapel Hill: University of North Carolina Press, 1998), xvi. 
eighteenth centuries. Few historians have examined the role that native women, or the idea of native women, has played in sixteenth-century encounters or how these perceptions differed across imperial lines. Commonalities and divergences in North American settings such as New France and Florida remain elusive in terms of scholarship. ${ }^{7}$

The purpose of this study is to provide greater insight into the roles and conceptualizations of women constructed by sixteenth-century conquistadors by juxtaposing two analogous but geographically distinct settings. Depictions of women in New France by Jacques Cartier, Samuel Champlain, and their followers in the northern borderlands of North America are compared to those depictions made by Hernando de Soto, Pedro Menendez de Avilés, and their contemporaries during the same general period in the southern borderlands. The accounts of these figures, who came from varied backgrounds and promoted differing world views, provide evidence for the earliest foundations of the "imperial gaze" 8 in reference to distant poles along North America's eastern seaboard. While often fleeting, these impressions undergirded later understandings of gender and indigenous cultures once extensive contact between Europeans and Indians become more frequent in the seventeenth and eighteenth centuries.

How explorers regarded native women in both regions, depended, at least in part, on native women's behavior related to conquistadors' ideals. In

7 General works addressing sixteenth-century European explorers and their understandings of North American indigenous women include Sandra Slater and Fay A. Yarbrough (eds.), Gender and Sexuality in Indigenous North America, 1400-1850 (Columbia: University of South Carolina Press, 2011); Kirsten Fischer, "The Imperial Gaze: Native American, African American, and Colonial Women in European Eyes", in ed. Nancy A. Hewitt, A Companion to American Women's History (Malden, MA: Blackwell, 2005), 3-19; Ann M. Little, "Gender and Sexuality in the North American Borderlands, 1492-1848”, History Compass 7/6 (2009), 16o6-1615; Anne McClintock, Imperial Leather: Race, Gender, and Sexuality in the Colonial Conquest (New York: Routledge, 1995); Juan Francisco Maura, Women in the Conquest of the Americas (New York: Peter Lang, 1997). Important works examining women and colonization in France include Karen Anderson, Chain Her by One Foot: The Subjugation of Women in $17^{\text {th }}$ Century New France (New York: Routledge, 1991); Barbara Alice Mann, Iroquoian Women: The Gantowisas (New York: Peter Lang, 200o); and Susan Sleeper-Smith, Indian Women and French Men: Rethinking Cultural Encounter in the Western Great Lakes (Amherst: University of Massachusetts Press, 2001). Few comparable studies on Florida exist, though notable works that address the topic in part include Kathleen Brown, "The Anglo-Algonquian Gender Frontier", in ed. Nancy Shoemaker, Negotiators of Change: Historical Perspectives on Native American Women (New York: Routledge, 1995), 26-48; Michelle LeMaster, Brothers Born of One Mother: British-Native American Relations in the Colonial Southeast (Charlottesville: University of Virginia Press, 2012).

8 Fischer, "The Imperial Gaze", 3-4. 
short, native women who acted in a docile, subservient, welcoming manner demonstrated native acceptance of European agendas and the success of the respective entradas whereas native women's actions or displays that deviated from accommodation or explorers' expectations of propriety threatened colonial designs. Even when the representations of native females did not directly impinge conquistador efforts, they became markers for unsettling European observers who emphasized their aberrant nature. Moreover, despite the various differences between French and Spanish explorers, these patterns emerged in both New France and Florida. North American borderland interaction separated by physical and cultural differences and seemingly few direct connections spawned a common Franco-Spanish gendered understanding of people and place. ${ }^{9}$

In another sense, conquistador writings demonstrate the influence and power that native women, at two extremes along the Atlantic seaboard, used to integrate European visitors into existing indigenous systems of reciprocity and fictive kinship. As Juliana Barr and others have demonstrated in reference to European-Indian encounters in seventeenth and eighteenth-century North America, native women employed a variety of tactics to situate colonists into indigenous-created exchange, diplomacy, family, and hierarchical relationships, often meeting success. Natives thus orchestrated power dynamics in these relationships as much as Europeans. ${ }^{10}$ Evidence for the development of similar modes of interaction can be found in the initial sixteenth-century encounters of Indians and those accompanying De Soto, Cartier, and their contemporaries. Nevertheless, despite the efforts of native women in Florida and New France to integrate the Europeans they met in ways similar to their seventeenth and eighteenth-century counterparts, integration remained limited and

This work attempts to examine the foundations of "colonial intimacies" as illustrated by Ann Marie Plame, "tender ties" as articulated by Sylvia Van Kirk, "intimate frontiers" as depicted by Albert Hurtado, and "geographies of intimacy" as conceptualized by Ann Stoler and others. See Ann Marie Plame, Colonial Intimacies: Indian Marriage in Early New England (Ithaca, N.Y.: Cornell University Press, 200o); Sylvia Van Kirk, Many Tender Ties: Women in Fur-Trade Society, 1670-1870 (Norman: University of Oklahoma Press, 1983); Albert L. Hurtado, Intimate Frontiers: Sex, Gender, and Culture in Old California (Albuquerque: University of New Mexico Press, 1999); and Ann Laura Stoler (ed.), Haunted by Empire: Geographies of Intimacy in North American History (Durham, NC: Duke University Press, 2006).

10 See Juliana Barr, Peace Came in the Form of a Woman: Indians and Spaniards in the Texas Borderlands (Chapel Hill: University of North Carolina Press, 2009); LeMaster, Brothers Born of One Mother; and Brown, "The Anglo-Algonquian Gender Frontier", for examinations of this idea. 
fleeting. The relative brevity of contact, absence of pre-existing frames of reference with which to interpret local "others", and exploration, rather than settlement, goals of conquistadors all played a part. In addition, male Europeans' reluctance to acknowledge female natives' independent power and influence in Florida and New France caused them to misunderstand or completely overlook the actions, words, and expectations of Indian women, often to the detriment of both groups.

\section{Natives in Florida and New France}

The women that European explorers encountered in both New France and Florida indigenous communities led varied and complicated lives. Much like the European men evaluating them, female Indians came from different backgrounds, pursued shifting strategies for survival, and took on multiple roles depending on the situation and cultural norms of their society. Also like the French and Spanish men they interacted with, native women often acted in ways that concealed their true motivations and intentions. Our knowledge of the lives that native women led during the sixteenth century and before is limited due to the paucity of available evidence today. Nevertheless, scholars from a variety of fields have provided an outline of their worlds that is quite distinct from the perceptions held by sixteenth-century conquistadors.

The female and male Indians first encountered by Europeans in Florida represented multiple culture groups and numerous interrelated communities. In the peninsular lands south of modern-day Tampa and Fort Pierce, Calusa Indians wielded the most influence. A fisher-hunter-gatherer people probably numbering less than 10,000 at the time of contact, the Calusas utilized a chiefdom form of government and enforced tribute demands on the region's other sizeable native groups, the Tequesta and Ais. Timucuan speakers, totaling almost 200,00o people prior to European contact according to some scholars, inhabited the central and northwestern portions of the peninsula. Aside from language, Timucuas shared few political or ethnic allegiances though all practiced some form of farming to supplement hunting, fishing, and gathering. Along what is today Georgia's south Atlantic coast lived about 15,00o Guale Indians. Dependent on farming, hunting, gathering, and marine life for survival, the Guales resembled the Timucuas in terms of political organization, possessing no single unified system and consisting of several small, independent chiefdoms connected through clan/kinship networks. The northern tier of Florida contained dozens of other native groups numbering in the tens of 
thousands as well, including the remnants of declining Mississippian-era societies such as the Coosas, Apalachees, and peoples of Casqui and Pacaha. ${ }^{11}$

In contrast, the first French explorers of New France addressed here encountered just three primary native polities. The largest Algonquian group living in present-day southern Quebec became known to French conquistadors as Mi'kmaqs. Subsisting on gathering, hunting, and marine life, these people had traded with European fishermen long before Cartier arrived in the early sixteenth century. Culturally adaptive, the Mi'kmaq enjoyed a fluid political system similar in some ways to both tribal and chiefdom structures. The group's overall pre-contact population may have been as high as 35,000, though there is much disagreement among scholars on this number. ${ }^{12}$ In the lands surrounding the mouth of the St. Lawrence River, specifically the QuebecLabrador peninsula, French explorers met Innu peoples whom they labelled Montagnais. Also gatherers, hunters, and fishers, the Innu traded widely with neighboring Algonquian and Iroquoian peoples for subsistence items. At the time of European contact, there may have been as many as 5,000 Innu living in multiple, decentralized "lodge group" communities comprised of three to four families. The Innu shared linguistic and cultural ties but fell under the authority of no single individual, apparently engaging in seasonal migrations. ${ }^{13}$

11 John H. Hann, Indians of Central and South Florida, 1513-1763 (Gainesville: University Press of Florida, 2003), 17-6o; Jerald T. Milanich, Laboring in the Fields of the Lord: Spanish Missions and Southeastern Indians (Washington, D.C.: Smithsonian Institution Press, 1999), 41-45, 50-54; Theda Purdue and Michael D. Green (eds.), The Columbia Guide to American Indians of the Southeast (New York: Columbia University Press, 2001), 37-46; Kathleen DuVal, The Native Ground: Indians and Colonists in the Heart of the Continent (Philadelphia: University of Pennsylvania Press, 2006), 20, 35-37, $5^{\circ}$.

12 Paul R. Magocsi (ed.), Encyclopedia of Canada's Peoples (Toronto: University of Toronto Press, 1999), 5, 16-17, 21; Olive P. Dickason and David T. McNab, Canada's First Nations: A History of Founding Peoples from Earliest Times (New York: Oxford University Press, 2009), 81-83, 86; Harold E.L. Prins, The Mi'kmaq: Resistance, Accommodation, and Cultural Survival (New York: Harcourt Brace, 1996), 24. For seventeenth and eighteenth-century European interactions with regional Algonquians, see Robert Grumet, "Sunsquaws, Shamans, and Tradeswomen: Middle Atlantic Coastal Algonkian Women during the $17^{\text {th }}$ and $18^{\text {th }}$ Centuries", in eds. Eleanor Leacock and Mona Etienne, Women in Colonization: Anthropological Perspectives (New York: Praeger, 1980), 43-62.

13 Edward S. Rogers and Eleanor Leacock, "Montagnais-Naskapi", in eds. William Sturtevant and June Helms Handbook of North American Indians. Volume 6 (Washington D.c.: Smithsonian Institution, 1981), 169-182; Magocsi, Encyclopedia, 5; Dickason and McNab, Canada's First Nations, 77, 81; Peter Armitage, The Innu (The Montagnais-Naskapi) (New York: Chelsea House, 1991), 13. For seventeenth-century European relations with the Innu, 
As they travelled west on the river, especially in the vicinity of Quebec City and Montreal, French conquistadors interacted with natives today known as St. Lawrence Iroquoians. The origins of sixteenth-century Indians living in this setting are still disputed by historians and archeologists today, as are their ties to Iroquoian peoples to the south and west. Most scholars agree, however, that by the seventeenth century, the St. Lawrence Iroquoians no longer lived in the region, either having perished or migrated elsewhere for unknown reasons. Of the three groups encountered by the French, the St. Lawrence Iroquoians were the only one to farm extensively, using their produce to supplement subsistence from gathering and hunting. No accurate population numbers for the group exists, though Jacques Cartier claimed that in 1534, the principle St. Lawrence Iroquoian town of Hochelaga served as home to 1,500 people. ${ }^{14}$

The geographic, demographic, and polity-specific differences among these communities make generalizations about the roles and motivations of native women living in Florida and New France problematic, especially related to the sixteenth century. Debates among anthropologists and historians generally addressing the topic in reference to the seventeenth, eighteenth, and nineteenth centuries do provide frameworks for evaluating earlier intercultural encounters, however. Native women neither willingly submitted to male (native or European) dictates nor functioned simply as oppressed laborers with no voice or power in their daily lives. At the same time, native women often held more public leadership positions and autonomy within their communities than women in Europe, though native, sex-status egalitarianism generally occurred in a fluid, situational form, depending on the specific social norms of the village or larger group. The eventual imposition of European gendered societal roles at times diminished the autonomy and rights of native women in their communities but female Indians continued to maintain a voice and substantive role in collective decision-making by revising and adapting their traditional roles to meet the challenges of their evolving worlds. Consequently, as the colonization process unfolded, native women, often more so than native men, preserved customary value systems in their extended kinship networks,

see Eleanor Leacock, "Montagnais Women and the Jesuit Program for Colonization", in eds. Eleanor Leacock and Mona Etienne, Women in Colonization: Anthropological Perspectives (New York: Praeger, 1980), 25-42.

14 Magocsi, Encyclopedia, 5, 56-57; Dickason and McNab, Canada's First Nations, 76; James F. Pendergast, "The Confusing Identities Attributed to Stadacona and Hochelaga", Journal of Canadian Studies 32, no. 4 (Winter 1997/1998): 149-167. For a broader view of native peoples living in eastern France, see Denys Delâge, Bitter Feast: Amerindians and Europeans in Northeastern North America, 160o-64 (Vancouver: U BC Press, 1993). 
maintained traditions in rapidly changing circumstances and integrated into Euroamerican processes while pursuing their own agendas. ${ }^{15}$

\section{Promise}

European men often depicted indigenous women as facilatators of New World colonization, though they rarely criticaly examined the basis of their depictions. ${ }^{16}$ Native women often appear receptive to European manifestations of "civilization" in exploration accounts, seemingly welcoming the presence of colonists, often in contradiction to native men engaged in opposing settler intrusion. In these depictions, women at times ensure settler survival while facilitating mutually beneficial prosperity for colonists and natives alike. Hospitable women functioned as portends of hope and future success to male Europeans. The motivations of such hospitality or analysis of alternate understandings of female actions received little attention from European chroniclers.

For example, sixteenth-century explorers often equated female native dancing and singing as portends of colonial success. These perceptions are evident in the writings documenting the early explorations of Jacques Cartier in

15 The vast literature highlighting these ideas as they developed over the past three decades is well summarized in Michelle LeMaster, “Pocahontas Doesn't Live Here Anymore: Women and Gender in the Native South before Removal", Native South 7 (2014): 1-32. Throughout this essay I have attempted where possible to emphasize the lens through which male conquistadors evaluated native peoples they encountered by providing possible motivations of native women for the activities Europeans observed. Absent a more thorough ethnohistorical methodological approach, which is outside the scope of this study, such interpretations on my behalf are intended less to specify definitive explanations for why native women acted the ways they did and more to emphasize alternate scenarios that the European men did not consider in their assessments.

16 For varied interpretations of this idea see Heidi Hutner, Colonial Women: Race and Culture in Stuart Drama (New York: Oxford University Press, 2001), 3-21, 24-29, 67-69; Karen V. Powers, Women in the Crucible of Conquest: The Gendered Genesis of Spanish American Society, 1500-160o (Albuquerque: University of New Mexico Press, 2005), 9-10; Nancy Shoemaker, A Strange Likeness: Becoming Red and White in Eighteenth-Century North America (New York: Oxford University Press, 2004), 105-24. Masculinity and its role in conditioning European men's understanding of native women in the Americas is examined in Sandra Slater, "Nought but women': Contstuctions of Masulinities and Modes of Emasculation in the New World", in eds. Sandra Slater and Fay A. Yarbrough (eds.), Gender and Sexuality in Indigenous North America, 1400-1850 (Columbia: University of South Carolina Press, 2011), $30-53$. 
North America. ${ }^{17}$ In 1534, Cartier embarked on his first voyage to modern-day Canada, exploring the Gulf of St. Lawrence, ultimately interacting with Innu, Mi'kmaq, and St. Lawrence Iroquoian Indians. Largely dedicated to mapping the region, surveying its peoples, and scouting future sites of French settlement, Cartier's first expedition consisted of three vessels and 61 men. Though the expedition stayed in what would become New France only a few months, Frenchmen generated impressions of the region's natives that would long endure. In early July, near Paspebiac Point on the north shore of Chaleur Bay, a tributary of the St. Lawrence River, the expedition encountered a group of natives, probably Mi'kmaq, whom they attempted to engage in trade. ${ }^{18}$ Cartier recorded that the Indians provided food and wished to row out to the ships in the harbor for barter. Pleased with this situation, the French leader emphasized the role of native women in the encounter. Noting the presence of men and children with little comment, Cartier explained that "their women, who did not pass over [to the ships], danced and sung, standing in the sea up to their knees". Other women approached the Frenchmen on land, "came freely to us and stroked their arms with their hands, and then raised their joined hands to the sky, making many signs of joy". ${ }^{19}$ To the Frenchmen, the behavior of female natives symbolized a successful interaction with indigenous peoples and initiation of bountiful trade relations, scenarios they hoped would further their North American endeavors. ${ }^{20}$

Descriptions of native women celebrating the French presence appeared on more than one occasion in Cartier's accounts. In mid-July 1534, on the coast of

17 Cartier's motivations on this and other voyages to North America appear to be primarily motivated by visions of material wealth, a similarity he had with Spanish conquistadors in Florida. See Marcel Trudel, "CARTIER, JACQUES (1491-1557)", in Dictionary of Canadian Biography, vol. 1 (University of Toronto/Université Laval, 2003), http://www.biographi.ca/ en/bio/cartier_jacques_1491_1557_1E.html (accessed January 3, 2016); and Jacques Cartier, Henry Percival Biggar, and Ramsay Cook, The Voyages of Jacques Cartier (Toronto: University of Toronto Press, 1993), xi-xvi.

18 Prins, The Mi'kmaq: Resistance, 43-47; Bruce G. Trigger, Natives and Newcomers: Canada's "Historic Age" Reconsidered (Montreal: McGill-Queen's University Press, 1985), 130.

19 James Phinney Baxter, Jean François de La Roque Roberval, Jean Alfonce, A Memoir of Jacques Cartier, Sieur de Limoilou: His Voyages to the St. Lawrence, a Bibliography and a Facsimile of the Manuscript of 1534 with Annotations, Etc. (New York: Dodd, Mead \& Company, 1906), 106; Henri Michelant and Alfred Ramé (eds.), Relation originale du voyage de Jacques Cartier au Canada en 1534 (Paris: Librairie Tross, 1867), n.p., http://www.guten berg.org/2/3/8/o/23801/ (accessed October 16, 2013); Cartier, et al., The Voyages, 22.

20 For an alternative assessment of native "singing" and its meanings to early French explorers in New France see John Haines, "The Earliest European Responses to Dancing in the Americas", U.S. Catholic Historian 30, no. 4 (Fall 2012): 1-20. 
Gaspé Bay, his expedition encountered another native community, Stadacona, comprised of Iroquoian people. Cartier's impressions on this introduction, especially of Indian women, resemble those previously formed in relation to the Mi'kmaqs. Meeting the Iroquoians as they fished along the banks, Cartier noted how they welcomed the French, prompting the explorers to row ashore. On this occasion, however, he remarked how the male natives met them with great joy but "caused all the young women to flee into the woods". Cartier described how "two or three ... remained", however, to which the captain "gave each a comb, and to each a little tin bell". In his words, these gifts made the women happy and they thanked the Frenchman "by stroking his arms and breast with their hands". Moreover, to Cartier these events apparently caused the native men to make "those [native women] return who had fled to the woods, in order to get from him as much as the others". Consequently, native women emerged from the nearby forest and, "gathered about the said captain, while stroking him with their hands, which is their style of endearment". Pleased, Cartier gave the women each "a little tin bell of small value" which caused them to immediately assemble together "to chatter and sing a number of songs". ${ }^{21}$ Secure in their position, Cartier and his men then surveyed the trade items they could obtain from the Indians and persuaded the primary headman of Stadacona, Donnacona, to allow two of his sons, Taiganoagny and Domagaya, to return to France with the expedition. ${ }^{22}$

In this instance, native men instructed native women to flee upon Cartier's arrival, at least according to his interpretation of the situation. Such an action would have been troubling to the French explorers since withdrawal of the women threatened the possibility of exchange and harmonious relations with the Indians. Yet Cartier's gift-giving reduced native fears, in his view, and led the men to command the women to interact with the French, thus creating a hospitable situation that fostered potentially beneficial trade between the groups. Cartier's interpretation of the native women's actions is questionable; the women themselves may have chosen to withdraw and interact according to their own designs, pursuing strategies of caution while engaging the French visitors. Past interaction with unknown fisherman or other visitors from Europe may have also encouraged the women to express satisfaction with the gifts as a means of facilitating trade relationships dictated, at least in part, by native females who often supervised the economic affairs of their

\footnotetext{
21 Baxter, et al., A Memoir of Jacques Cartier, 109-110; Michelant and Ramé, n.p. Rather than a "bell", Cook contends that Cartier gave the native women each a "ring". Cartier, et al., The Voyages, 25 .

22 Dickason and McNab, Canada's First Nations, 73; Trigger 130.
} 
communities. ${ }^{23}$ Regardless, the actions of women on this occasion once again symbolized success of French exploration endeavors.

The next year, 1535, Cartier returned to the region on a second expedition, but his understanding of female natives remained largely unchanged. Returning to Stadacona in early September, where his contingent had engaged in trade with Indians on the previous voyage, Cartier and his followers again experienced what they deemed to be a friendly interaction. Upon leaving the town in search of a water route westward, Carter emphasized the actions of native women. As the French ships departed, women of the village "danced and sang without ceasing, being up to their knees in the water. Our captain, seeing their love and good will ... gave them some knives and little paternosters of glass, whereat [sic] they showed a marvelous joy". Impressed with this display, Cartier concluded the passage by stating "we, having departed from among them a distance of a league, or thereabouts, heard them sing, dance, and make glad of our coming". ${ }^{24}$

On this occasion, as in others, Cartier's depiction of native women and their behavior is suspect. Though they may have been joyous at once more having met the Frenchman and his followers, the Indians also may have been demonstrating their happiness over the expedition's departure from the town. Moreover, acting in the manner they did corresponded with traditional native diplomatic rituals of departure that had little to do specifically with Cartier

23 Native women's resistance to European economic influence in early New France is addressed in Carol Devens, "Separate Confrontations: Gender as a Factor in Indian Adaptation to European Colonization in New France", American Quarterly 38, no. 3 (1986): 470-472. For the role of native women as "negotiators of change" in New France's western fur trade, see Susan Sleeper Smith, "Women, Kin, and Catholicism: New Perspectives on the Fur Trade", Ethnohistory 47, no. 2 (Spring 2000): 423-452. On Iroquoian women and their roles in welcoming strangers as a means of evaluating their overall intentions and exchange-related potential, see Mann, Iroquoian Women, 229-231; and Roland Viau, Femmes de personne: Sexes, genres et pouvoirs en Iroquoisie ancienne (Montreal: Boréal, 200o). Further assessment of Iroquoian women and their key roles in community economic decisions and gift exchange can be found in Judith K. Brown, "Economic Organization and the Position of Women among the Iroquois", Ethnohistory 17, nos.3 and 4 (Summer/Fall 1970): 151-167; Jan V. Noel, "Revisiting Gender in Iroquoia", in eds. Sandra Slater and Fay A. Yarbrough Gender and Sexuality in Indigenous North America, 1400-1850 (Columbia: University of South Carolina Press, 2011), 54-74.

24 Baxter, et al., A Memoir of Jacques Cartier, 146-147; Jacques Cartier, Voyage de J. Cartier au Canada Relation originale de Jacques Cartier (Paris: Librairie Tross, 1863), 14, http://www .gutenberg.org/files/12356/12356-h/12356-h.htm (accessed October 20, 2013). Rather than "paternosters" of glass, Cook uses the word "beads" in his translations. Cartier, et al., The Voyages, 51 . 
and simply followed established protocols for dealing with visitors leaving their community. In another sense, the native women may also have been trying to extract additional European goods from the expedition without having to exchange their own items in the process, a calculation that seemed to succeed based on Cartier's account. Apparently he chose not to acknowledge these possibilities and instead viewed the actions of native females as an endorsement of his colonial ventures. ${ }^{25}$

A similar situation took placed on the outskirts of Hochelaga, another Iroquoian town. As Cartier's expedition approached the setting in late September 1535, numerous natives (men, women, and children) gathered to welcome it to their community. The French responded as before by distributing gifts. On this occasion, however, according to Cartier's accounts, "the women brought their children in their arms to make them touch the said captain and others, making a rejoicing which lasted more than half an hour". In response, "our captain, witnessing their liberality and good will, caused all the women to be seated and ranged in order, and gave them certain paternosters of tin and other trifling things". Cartier then retired to his ship while the Indians remained dancing and celebrating his arrival well into the night. ${ }^{26}$

Key to each of these patterns of interaction is what the Frenchman emphasized in his assessment. Native welcoming of the expedition did not only involve women yet women garnered more attention in the accounts. Moreover, these encounters typically cost Cartier very little in terms of trade goods; most relevant passages highlight that the Frenchmen acknowledged native hospitality generally by providing insignificant items, or "trifling things" to the Indians. Presented with a host of native actions to comment on, French accounts often focused on the perceived benevolence and compliance of native womenfactors the conquistadors assumed they could control in an environment where few things seemed controllable.

Spanish conquistadors in Florida echoed these perceptions and assessments in the mid-sixteenth century. Since at least 1513, explorers representing Spain had traversed the peninsula looking for gold, slaves, and passages to Asia. In most regards, they failed to find what they sought. Seeking signs of hope or prosperity in a land quite different from New France in terms of

25 For an overview of European/Euro-American gift-giving and its meanings to native peoples in Canada during the nineteenth century and beyond, see Cary Miller, "Gifts as Treaties: The Political Use of Received Gifts in Anishinaabeg Communities, 1820-1832", American Indian Quarterly 26, no. 2 (2002): 221-245.

26 Baxter, et al., A Memoir of Jacques Cartier, 161-162; Cartier, Voyage de J. Cartier, 22. Cartier, et al., The Voyages, 60 . 
climate, geography, and demographics, Spaniards too focused on native women. Chroniclers of exploratory ventures in Florida generally connected their prosperity, successes, or even hope in the region to the roles played by female natives deemed acquiescent and welcoming of men from Spain. ${ }^{27}$

Missionaries accompanying the Trístan de Luna y Arellana expedition in 1560 associated the mere presence of native women in the town of Coosa with Spanish prospects of success and positive relationships with local Indians. Charged with establishing a settlement on the Gulf of Mexico near presentday Pensacola, Florida, Luna and his men eventually hoped to traverse the peninsula and establish a Spanish presence along the coast of modern South Carolina as well. A variety of factors disrupted the expedition's plans, including encounters with hostile Indians, insufficient food sources, and disagreements among the conquistadors on the expedition as to Luna's leadership abilities. Consequently, the expedition proceeded haphazardly, meandering north into Alabama and Georgia as it continued eastward. Near present-day Rome, Georgia, members of the expedition entered Coosa, a native town that by 1560 was largely abandoned. Fray Domingo de la Anunciación, on behalf of his fellow explorers, wrote than in the town they "found the chief and all his people in their houses, and they made no move to take away their food or women, as if they had talked and had dealings with us before this". Apparently not realizing or appreciating that the local natives' history with Spaniards may not have been peaceful, the priest viewed this situation positively. Pleased that the Indians had not violently resisted the expedition, as had occurred earlier on his travels, Fray Domingo de la Anunciación concluded, "They are apparently such good Indians that they are at ease with all the Spaniards, and show goodwill". 28

Like Cartier, the Spanish priest may have misperceived native actions in Coosa. Indians probably concealed themselves from Luna's expedition out of fear; residents of the town had interacted with Spanish explorers before, most notably Hernando de Soto's entrada of 1539-1540, an experience the native survivors surely regretted due to the violence and theft that took place. Memories of Indians attempting to flee the Spanish while being pursued and

27 For an alternate viewpoint of European men and how they incorporated native women into their visions of the Americas, see M. Carmen Gomez-Galisteo, "Suberting Gender Roles in the Sixteenth Century: Cabeza de Vaca, the Conquistador Who Became a Native Woman", in eds. Sandra Slater and Fay A. Yarbrough, Gender and Sexuality in Indigenous North America, 1400-1850 (Columbia: University of South Carolina Press, 2011), 13-15.

28 Herbert Ingram Priestly, The Luna Papers: Documents Relating to the Expedition of Don Tristán De Luna Y Arellano for the Conquest of Florida in 1559-1561 (Freeport, NY: Books for Libraries, 1971), 1:228-231. 
killed by dogs made staying in their houses a better option. Equally important, the missionary made assumptions about male direction of female actions that commonly took place in conquistador accounts throughout the Atlantic borderlands of North America. Though it is impossible to know for certain based on the available evidence, native women may have dictated overall town reactions to European expeditions, not to mention their own actions and inaction upon Fray Domingo de la Anunciación's arrival.

Spanish and French explorers noted the seeming hospitality of native women in day-to-day interactions, but they also focused on the role that female Indians played in different forms of intercultural diplomacy. In both New France and Florida, European conquistadors realized that the actions of native women often reflected the tone of their negotiations with native men and harmony of interactions. This realization was largely superficial, however. ${ }^{29}$ Rather than acknowledge the leadership and decision making functions native women often played in negotiations, Europeans typically viewed them more in light of the perceived connotations of their activities. In both regions, conquistadors placed more value on the attitudes and accessibility of native women then on their potential conditioning of native perspectives and stances in terms of diplomacy. Simply put, instead of recognizing their actual roles in diplomatic interactions, Spaniards and Frenchmen focused on whether native women appeared to be cordial towards Europeans more than anything else.

In Florida, Spanish optimism regarding diplomacy with Indians manifested itself in depictions of women and their role in native acceptance of Spanish dominion. One example involves the first governor of Florida, Pedro Menéndez de Avilés. In many ways, Menéndez followed the same path to Florida as the conquistadors who preceded him. Upon learning of the French settlement of Fort Caroline in 1564, Spain's King Phillip II decided to militarily expel the perceived trespassers and reinforce Spanish claims to the region by establishing a permanent settlement. To lead the expedition he chose Menéndez, a soldier and sailor experienced in defending Spain's Western Hemisphere empire from European competitors. Promised noble titles, land grants, and administrative control of Florida by the king if successful, Menéndez assembled an armed contingent of at least ten ships and one thousand soldiers for the undertaking. After encountering and dispersing a French fleet sent to defend Fort Caroline, Menéndez quickly reinforced Spanish claims to the region by establishing the settlement of St. Augustine. He then proceeded to launch a

29 An early overview of this process is available in Clara Sue Kidwell, "Indian Women as Cultural Mediators", Ethnohistory 39, no. 2 (Spring 1992): 97-107. 
surprise attack on Fort Caroline. The outnumbered and physically debilitated inhabitants surrendered, hoping for merciful treatment. Menéndez, for reasons still disputed by historians, ordered his soldiers to kill the French settlers immediately. As a result of his actions and decisions made by imperial administrators, French settlement efforts associated with Fort Caroline came to an end, as did any serious French colonization attempts on the south Atlantic coast of North America. ${ }^{30}$

Following expulsion of the French, Governor Menéndez entered into an alliance with a Calusa headman name Carlos (Calos). In recognition of the alliance, Carlos arranged an elaborate celebration involving dozens of Calusas participating in singing and dancing. As in previous encounters, the role of women in this celebration appeared in the accounts of the proceedings, some of which later were published in Spain under the title Vida y hechos de Pedro Menéndez de Avilés ... largamente se tratan las Conquistas y Poblaciones de la Provincia de Florida. According to the work's author, Bartolomé Barrientos, ${ }^{31}$ when the Spanish arrived at the ceremony organized by Carlos, "the Indian women" rose before Menéndez and clasped his hands. "Every one of the natives seemed to exhibit the greatest joy" recorded the chronicler, "and the Indian girls outside the windows did not leave off singing. They were formed in groups of a hundred, and sang alternately, fifty at a time". More revealing as to Spanish notions of gender, power, and colonialism, however, was Barrientos's detailed depiction of Menéndez's placement during the ceremony. In the chronicler's words, when "the Adelantado entered, the cacique gave him his own seat, and the gathering drew aside for him". Below Menéndez sat fifty male headmen and below them sat fifty Indian women. In a physical and figurative sense, Menéndez had replaced Carlos in his position of authority over the village's Indians and literally towered over them. Significantly, an "Indian woman

30 The most detailed assessment of Menéndez and his role in Florida is Eugene Lyon, The Enterprise of Florida: Pedro Menéndez de Avilés and the Spanish Conqust of 1565-1568 (Gainesville: Unviersity Press of Florida, 1976).

31 A Latinist, noted author, and contemporary of Menéndez, Barrientos clearly admired the subject of his work, referring to the governor's exploits in Florida as "outstanding deeds zealously accomplished by him with rare industry and insight". Barrientos based his treatment of Menéndez on "the letters, decrees, royal orders, and instructions" of the Spanish government and "the eyewitness accounts of military men and others who took part in the Florida enterprise". See Bartolomé Barrientos, Pedro Menéndez de Avilés, Founder of the Floridas, trans. Anthony Kerrigan (Gainesville: University Press of Florida, 1965), vii, xxi, $5^{-6}$. 
[Doña Antonia] was seated at his side, a little apart and on an elevation half a man's height from the ground". ${ }^{32}$

Said another way, native women proved instrumental in the completion of the diplomatic agreement. In this situation, not only did women play a prominent role in facilitating intercultural harmony, they did so in a way that removed native male dominance while leaving in place the subordinate, but advantageous function of native women. Perhaps realizing the ceremony's symbolism to the native audience, Menéndez took Doña Antonia's hand "and seated her between" himself and Carlos. By this last action, Menéndez indicated his assumptions regarding Spanish-Indian relationships in Florida. While all natives must be subservient to the will of Europeans, native women could function as the catalyst for alliances that would be mutually beneficial for both groups. In the end, women's subservience, at least to the conquistadors, fostered cross-cultural harmony.

Cartier also embraced similar understandings of diplomacy with Indians while introducing European notions of order in New France. The day after his arrival at Hochelaga in the fall of 1535, and the native women's dancing and singing that accompanied it, Cartier and his men entered the town for an audience with its leaders. Once he was taken to the area designated for the audience, women again appeared before the Frenchmen prior to any discussions taking place. "And suddenly all the women and girls of the said town gathered together", according to Cartier's memoirs, "a part of whom were burdened with children in their arms, and who came to us to stroke our faces, arms and other places upon our bodies that they could touch; weeping with joy to see us; giving us the best welcome that was possible to them and making signs to us that it might please us to touch their said children". At this point, the women withdrew and the native men joined the Europeans to commence talks. Cartier expressed pleasure at what followed as the native headmen requested help from the French contingent to heal the sick, an opening Cartier used to instruct the natives about Christianity. Pleased with this sequence of events, the French leader "made all the men range themselves on one side, the women on another, and the children another, and gave to the chiefs hatchets, to the others knives, and to the women paternosters and other trifling articles". Then providing the assembled children with toys and playing music for the Indians with trumpets and other instruments, Cartier and his men prepared to go back to their ships. "Seeing this, the women put themselves before us for to stop us, and brought us of their victuals, which they had prepared for us, as fish, stew, 
beans, and other things, thinking to make us eat and dine at the said place". Rather than stay for the feast, Cartier, "because the victuals were not to our taste and had not savor of salt" declined the food, thanked the women, and along with his men, departed for their ship. ${ }^{33}$

Native women in this situation influenced negotiations in the eyes of Cartier. Their hospitality and generosity appeared to help convince the male leaders to be receptive to French influence. At the same time, by segregating the native men, women, and children and presenting them with different types of gifts, Cartier again asserted European notions of patriarchy and hierarchy in his dealings with the Indians. It appears that Cartier once more underestimated the strategic meanings in women's actions, however. Presenting their children to Cartier opened the path for future dialogue by allowing the French to show their willingness to accede to native wishes ("it might please us [the French] to touch their said children"). In addition, by refusing the food provided by the women, Cartier probably undermined some of the progress he had made in attempting to Christianize the Indians or employ them in furthering his colonial designs. While correct in their recognition of women's role in facilitating diplomacy, the French misunderstood the implicit actions of the women and the potential consequences of failing to read their actions correctly.

Even in diplomatic negotiations that did go as desired, European conquistadors viewed the role of native women as potentially helpful. For a variety of reasons, relations between Indians and Spanish in Florida and Indians and French in New France deteriorated as the sixteenth century progressed. In the north, members of Cartier's expedition increasingly became obsessed with finding mineral wealth and believed the Indians played a key role in leading them to it. Unable to locate any minerals they could profit from, however, Cartier determined that he should once more take back to France Indians who could testify to the King and others of the mineral wealth that could be found in New France, thus justifying his expeditions to the region. His decision to seize the headman Donnacona, and his two sons a second time, for this purpose incited much consternation and upheaval among his followers in the town of Stadacona. Repeated entreaties for Donnacona's release by men from the town proved unsuccessful. As Cartier's ships prepared to depart for France in May 1536, women took the lead in attempting to insure Donnacona's safety. A boat from the village rowed to the ships "in which there were four women, without having any men in it". Cartier assumed that the absence of native men occurred because "for doubt that they had that we might detain them", and

33 Baxter, et al., A Memoir of Jacques Cartier, 167-169; Cartier, Voyage de J. Cartier, 26; Cartier, et al., The Voyages, 63-64. 
did not seem to believe the women had made this decision for any other reasons. The women brought "victuals, to wit, great millet (which is the corn on which they live), flesh, fish, and other provisions after their manner". Cartier greeted the women and, allegedly at the behest of Donnacona, told them that the headman would be returned to Stadacona within twelve months. In the French leader's words, this mollified the women who "made a great display of joy, showing by signs and words to the said captain that should he return and bring back the said Donnacona, they would make him many presents. Then each one of them gave to the said captain a collar of esnogy [a wampum belt], whereupon they went to the other side of the river". ${ }^{34}$

As on many previous occasions, Cartier highlighted the actions of native women but did not see the full spectrum of the possible meanings in them. The French leader and his followers apparently did not understand the Iroquoian gantowisa, a political and judicial leadership position that both men and women could hold and use to govern community affairs, or the common female role of Speaker, the individual designated to present community views to others. ${ }^{35}$ Viewing the women's actions as benevolent and directed by men, the Frenchman failed to recognize the key role the native women played in what the people of Stadacona no doubt viewed as a vital diplomatic negotiation with Cartier. By promising presents to Cartier upon Donnacona's release, they believed that Cartier would honor his pledge to return the native leader within the year. Such an agreement typified native diplomacy throughout eastern North America both before and after this time. That Cartier betrayed his pledge and Donnacona never returned to his village undermined native faith in European promises, a pattern that would continue for centuries.

In addition to hospitality and diplomacy, native women literally saved the lives of European explorers. While proceeding northward across the peninsula in 1539, the previously referenced and long-studied Hernando De Soto and his soldiers unexpectedly met Juan Ortiz, a member of an earlier Spanish expedition to the region. ${ }^{36}$ Abandoned by his fellow Spaniards and then held prisoner for more than twelve years by Timucua Indians, Ortiz provided De Soto's chroniclers with an extraordinary tale of his survival in the region. Detained shortly after arriving in Florida by followers of the headman Ucita, Ortiz was

34 Baxter, et al., A Memoir of Jacques Cartier, 205; Cartier, Voyage de J. Cartier, 44; Cartier, et al., The Voyages, 86 .

35 Mann, Iroquoian Women, 116-117, 165-166, 182; Brown, "Economic Organization", 155; Noel, "Revisiting Gender", 65.

36 Juan Ortiz was a member of a rescue contingent that Spanish colonial officials sent to find members of the Pánfilo de Narváez expedition after its disintegration in 1528 . 
"bound hand and foot to four stakes, and laid upon scaffolding, beneath which a fire was kindled, that he might be burned". At that point a female Indian intervened to save his life. Just when his death appeared a certainty, "a daughter of the chief entreated that he might be spared". According to the account written by the Portuguese "Gentleman of Elvas", ${ }^{37}$ a recorder of De Soto's experiences in Florida, Ortiz's savior justified her actions by explaining, "Though one Christian ... might do no good, certainly he could do no harm, and it would be an honor to have one for a captive". ${ }^{38}$ Ortiz experienced further travails before meeting De Soto's contingent, but after this incident Ucita allowed him not only to live but also to become a member of his community, a situation in which Ortiz flourished, eventually earning distinction and respect from the local Timucuas. To De Soto's men and future European audiences, this account had additional meaning; after being saved from execution by a native woman and learning much from the Indians, Ortiz joined De Soto's group and functioned as a valuable interpreter and guide, allowing the Spanish to gain more information about the region and promote their imperial agendas. ${ }^{39} \mathrm{~A}$ "daughter of the chief" not only directly saved a Spanish man's life but also indirectly furthered the efforts of future Spanish expeditions in Florida.

French conquistadors in New France also acknowledged the role of native women in preserving the health of explorers, though in a different context. By the spring of 1536, several of the Frenchmen on Cartier's second expedition were experiencing the ill effects of constant travel over rough terrain, inconsistent food and sleep, and other maladies. Searching for relief from the various ailments, Cartier turned to the Indians for help. Prior to his forced return to France, Domagaya, one of Donnacona's sons, told Cartier about the leaves of a certain tree that had healing properties. After Cartier requested that he reveal the location of this healing tree, Domagaya sent "two women with the captain to fetch some of it [the leaves]". Not only did the women take Cartier to the

37 Perhaps named Alvaro Fernandez, the Gentleman of Elvas was a Portuguese member of the expedition who provided the first published narrative (1557) of its activities based on his memory of events. Written upon the author's return to Spain, this depiction is considered by historians to be "the best full account" of the expedition. See Theodore H. Lewis, "The Narrative of the Expedition of Hernando de Soto by the Gentleman of Elvas", in eds. Frederick W. Hodge and Theodore H. Lewis, Spanish Explorers in the Southern United States, 1528-1543 (Austin: Texas State Historical Association, 1984), 129-130.

38 Edward G. Bourne, ed., Narratives of the Career of Hernando de Soto in the Conquest of Florida, as Told by a Knight of Elvas, and in a Relation by Luys Hernández de Biedma, Factor of the Expedition. 2 vols. (New York: Allerton, 1922), 1:28.

39 Jerald T. Milanich, Florida Indians and the Invasion from Europe (Gainesville: University Press of Florida, 1995), 129. 
tree, they "brought nine or ten branches of it, and showed us [the Frenchmen] how one should strip the bark and the leaves from the said tree and put the whole to boil in water, then to drink of it every other day and put the refuse on the swollen and diseased legs, and that the said tree would cure all the sick". Though some of his men were reluctant to ingest the medicine, Cartier noted that the few who did so regained their health, causing the other members of his expedition to clamor for it themselves. In the French leader's view, "for all the sick, of whatever they were infected, after having drunken of it two or three times, recovered health and vigor". Cartier did not directly acknowledge native women's role in the healing of his men, instead chalking it up to a miracle of god. Yet as in previous descriptions of positive experiences on his travels in New France, native women played a prominent role in sustaining European life and enabling colonialism. ${ }^{40}$

Native women offered European men hospitality, orchestrated diplomacy, and helped save their lives in sixteenth-century North America. But Spanish and French explorers more often emphasized the advantageous consequences of female Indians submitting to European authority. Men's accounts of Florida and New France during this period emphasize submission of native women to colonist desires in varied situations. This type of encounter is common in historical literature dealing with Latin America and North America, as well as colonized regions in general. ${ }^{41}$ Native women in this scenario provide European colonizers with security and wealth while surrendering their autonomy. Depictions of native women as symbols of exchange and European domination appear in both Spanish and French accounts. Fundamental to these depictions is the general acquiescence of women to male dictates. Women in these scenarios are forcibly restrained or exchanged by men to promote goodwill or profits. The gendered mind-set that emerges in these accounts is predicated on the frequently blurred perception of female submission and female hospitality. To European chroniclers and audiences, both in Florida and New France, conquistadors' dominance of native women, as evidenced through their activities and attitudes, was necessary to ensuring colonial success. ${ }^{42}$

40 Baxter, et al., A Memoir of Jacques Cartier, 167-169; Cartier, Voyage de J. Cartier, 38; Cartier, et al., The Voyages, 80.

41 See Fischer, "The Imperial Gaze", 4, 6-7; Powers, Women in the Crucible of Conquest, 9-10; Shoemaker, A Strange Likeness, 105-124; Slater, “Nought but women", 34-35.

42 See Colin Calloway, New Worlds for All: Indians, Europeans, and the Remaking of Early America (Baltimore: Johns Hopkins University Press, 1997), 91-192; Fischer, "The Imperial Gaze", 6-7; David J. Weber, The Spanish Frontier in North America (New Haven: Yale University Press, 1992), 329-332; Mann, Iroquoian Women, 23. 
Such a situation took place in Florida on the previously mentioned De Soto expedition as it passed through lands inhabited by Timucua Indians. Disembarking in the Tampa Bay area and journeying through north-central Florida, De Soto failed to find the riches he sought and increasingly alienated the Indians he encountered. As he neared the town of "Aguacalecuen" near the Suwanee River, the Spanish leader looked for ways to ensure his expedition's safety while utilizing the Timucuas in his search for wealth. According to Luys Hernandez de Biedma, a member of the expedition, De Soto "caught ten or twelve women, one of whom was declared to be the daughter of the Cacique" in hopes of engaging the village's leaders in discussions for guides and supplies. Rather than incite violence, the "consequence was, that her father came to us [the Spanish soldiers] in peace". ${ }^{43}$ Afterwards, De Soto made the peace-seeking cacique a hostage and interrogated residents of the village, learning much about the land and native peoples living to the north. When the Spanish force departed the village, it took the cacique and his daughter with them, probably to serve as porters and negotiators. ${ }^{44}$

Different from the earlier scenarios, this example de-emphasizes the autonomy of female natives. Their lack of independence promotes intercultural connections while establishing Spanish conquistadors as the dominant power. Seizing native females allowed De Soto to force the cacique to negotiate on terms dictated by the Spaniards. Native women continue to play a vital role in European-Indian relationships but in a diminished position. Biedma depicts the situation as one in which male Spaniards used female natives to gain control over male natives.

The physical possession of native women also played key roles in intercultural power relationships developing in sixteenth-century New France. Such an arrangement took place on Cartier's second voyage and involved the previously mentioned Iroquoian headman Donnacona, leader of Stadacona. Prior to his capture by the French, Donnacona worried that Cartier and his men would visit the rival Iroquoian village of Hochelaga, a visit that eventually took place. To help persuade Cartier and his men not to visit Hochelaga, Donnacona arranged a ceremony to flatter the Frenchmen. Surrounded by singing and dancing Indians, Donnacona gave a speech during the ceremony to impress the visitors. As he spoke, the headman, "holding a girl of about the age of ten years by one of his hands, then came to present her to our captain". Donnacona then commanded two younger boys to accompany the girl. As the other 
natives present at the ceremony celebrated the exchange, one of Donnacona's lieutenants "told the captain that the girl was the own daughter of the sister of the said lord Donnacona". Another native present at the ceremony explained that "the said lord had given him [the captain] the said children through good will and in token of confidence". The exchange did not have the desired effect; Cartier and his men continued their preparations to visit Hochelaga. Nevertheless, the exchange did appear to benefit both leaders. Taking the children to his ships, the Frenchmen returned with a brass basin which they "made a present to the said Donnacona who was greatly pleased therewith and thanked our captain". 45

In this instance, the transfer of a female native to French control seemed to reduce tensions in the minds of Cartier and his followers. Though Donnacona did not convince the conquistadors to change their minds regarding a visit to Hochelaga, he did seem to insure that bonds between his community and the French remained on friendly terms through the exchange. As it turned out, Cartier again misunderstood the situation. Despite offering the children to Cartier and allowing him to depart with them, Donnacona continued to disapprove of French interactions with his rival village. This disagreement would lead to strained relations between Cartier's contingent and the Stadacona natives in future encounters and the seizure of Donnacona and his sons.

Shortly after departing Donnacona's community on their way to Hochelaga, Cartier and his men had a similar encounter with another group of natives. Little information is provided in the accounts on these Indians but they probably came from Stadacona or fell under Donnacona's influence as a subordinate or ally. While traveling west on the St. Lawrence River, a number of boats carrying these natives rowed up to the side of Cartier's ship, one of them carrying a headman (labeled as a "lord") who through his words and hand gestures indicated that the Frenchmen should be careful since the river ahead was dangerous. After issuing the warning, the headman "presented to the captain two of his children as a gift, of which the captain took a girl of the age of about eight to nine years, and refused a boy of two or three years because he was too small". Pleased with the "gift", the information, the concern of the natives, or a combination of all, "The said captain entertained the said lord and his band with whatever he could, and gave him some small present; for which the said lord thanked the said captain". Cartier's memoir notes that at some unspecified alliance" in his translations. Cartier, et al., The Voyages, 54. 
point in the expedition's future, "the said lord and his wife" travelled inland "to see their daughter, and brought some presents to the captain". ${ }^{46}$

As mentioned, Spanish conquistadors in Florida too acknowledged the benefits of obtaining control of native women, even when the means by which they took possession of them involved violence. In September 1539, while exploring the western side of the peninsula, De Soto's exploratory force enslaved "a hundred men and women" to fulfill a variety of manual labor tasks for the Spaniards. "They were led off in chains, with collars about the neck", recorded one chronicler, in order to ensure their submission and prevent rebellion. De Soto's men employed these tactics in light of past incidents involving enslaved natives, mostly men, who attempted to kill their captors or escape from them during the journey. Yet, women became more docile once enslaved, at least in the opinion of the soldiers on the expedition. According to the Gentleman of Elvas, "The women ... when removed a hundred leagues from their country, no longer cared" and apparently stopped resisting their enslavement by the Spaniards. At that point, the women did not require chains or collars, and they performed the labor demanded by their captors. Moreover, within "a very little time" at least some of the newly captured native women succeeded in learning the Spanish language. ${ }^{47} \mathrm{On}$ an expedition where armed resistance from native men took place frequently, native women, in this scenario, not only submitted to Spanish desires, but seemingly embraced the manifestations of European civilization. In addition, multilingual native women served as potential facilitators of exchange between colonists and Indians to Spanish conquistadors, especially those familiar with the benefits of Malintzin's language skills for Cortés during his military conquest of Mexico.

Yet on other occasions, Spanish explorers in Florida placed emphasis on native women's surrendering voluntarily to colonists at the behest of male native leaders hoping to offset hostilities. ${ }^{48}$ Traveling through Florida's northwestern borderlands (present-day Arkansas), De Soto's soldiers entered the town of Casqui in late 1541. Though the town's cacique welcomed De Soto in peace and provided his men with supplies, relations between the two groups soon worsened. De Soto became enraged when natives of Casqui pillaged a neighboring town, Pacaha, and then hid from the Spanish soldiers, fearing they would claim the goods seized. Hoping to arrange peace between the two towns for his

46 Baxter, et al., A Memoir of Jacques Cartier, 156-157; Cartier, Voyage de J. Cartier, 20; Cartier, et al., The Voyages, 54.

47 Bourne, Narratives of Hernando de Soto, 1:45-46.

48 For similar examples see James Axtell, Native and Newcomers: The Cultural Origins of North America (New York: Oxford University Press, 2001), 30-31. 
own security, De Soto demanded that the headman of Casqui apologize for his people's actions. After hiding for several days, the "chief of Casqui" appeared before the Spaniards, giving them "many shawls, skins, and fish". He then offered his daughter to De Soto, "saying that his greatest desire was to unite his blood with that of so great a lord as he was, begging that he would take her" as a wife. Though it is unclear from available evidence how De Soto responded to the cacique's request, the Gentleman of Elvas recorded that afterwards the Spanish conquistador invited Indian leaders of both towns to a banquet where he arranged a peace agreement between them. Forty days later, as the Spaniards prepared to leave the region, a headman of Pacaha expressed his appreciation to De Soto by bestowing "on him two of his sisters, telling him that they were tokens of love, for his remembrance, to be his wives". Again, it is unclear if De Soto accepted the women as wives but the Gentleman of Elvas recorded that the women "were symmetrical, tall and full", with one of them bearing "a pleasant expression; in her manners and features appeared the lady; the other was robust". ${ }^{49}$ Or, to De Soto and his male followers, whereas the native men of Casqui and Pacaha caused problems for the Spaniards, native women from the same locales symbolized peace and pleasure.

More than two decades later a similar exchange took place involving local natives and Florida governor Pedro Menéndez de Avilés. As noted, following the execution of French settlers, Menéndez turned his attention to local Indians, hoping to use them to keep out future European interlopers and find the riches he and the crown desired. In his writings, Barrientos described a meeting between Menéndez and the afore mentioned Carlos, the native cacique who presided over Calusa Indians living along the peninsula's western coast and helped form an alliance with the Spanish. Despite the previously described ceremony celebrating the accommodation, both groups soon distrusted one another leading to physical conflicts. But according to Barrientos, native women served as bridges to accommodation. Carlos approached the Spanish governor in hopes of ending the feuding and reestablishing the alliance. Declaring that "he wished to adopt Menéndez as his elder brother so that he could carry out the Adelantado's wishes", Carlos "then offered Menéndez his own sister [the previously mentioned Doña Antonia], older than he and whom he dearly loved, to be his wife". In explanation, Carlos claimed that as long as Menéndez allowed the woman to eventually return to her homeland, "all the Indians would become Christians, for it now seemed better to be a Christian than to be an Indian".50 In the short term, relationships improved between

49 Bourne, Narratives of Hernando de Soto, 1:116-29.

5o Barrientos, Pedro Menéndez de Avilés, 85, 91. 
Spaniards and Indians after this meeting. Menéndez apparently claimed that he consummated his marriage to Doña Antonia the same night he "received" her. She subsequently went to Cuba to guarantee her brother's obedience to Menéndez, later returning to her home town as Carlos originally requested. In the meantime, Menéndez persuaded Carlos to allow a garrison of Spanish soldiers and missionaries to reside in his village and arranged a peace agreement between Carlos and the headman of a neighboring community with which his people were at war. ${ }^{51}$ Tensions between Indians and Spaniards eventually worsened for a variety of reasons, leading to intercultural warfare that often characterized relationships during the colonial period. In this particular situation, however, native women again symbolized accommodation and colonial success to Spanish observers. Much like earlier encounters in Florida and other North American borderlands, hostilities diminished, at least according to the words of Spanish men, after the submission of a native woman to Spanishand in this case, native-male wishes.

\section{Disillusionment}

Yet there were exceptions to this pattern. Explorers in Florida and New France also described interactions with native females that did not represent experiences or customs that they viewed favorably. On these occasions, conquistadors expressed alarm or disapproval of native communities based on the actions or manifestations of native women. While still not fully acknowledging female Indians' agency or strategies in these interactions, Europeans did see the possible negative consequences on colonial endeavors in North American borderlands stemming from them. Just as they tended to interpret female dancing and gift giving as positive signs for colonization ventures, French and Spanish explorers regarded native women's seeming disobedience or refusal to represent European ideals as negative factors in North America's exploitation and settlement. ${ }^{52}$

Cartier first referenced the potential negative impact of native women in his descriptions of the St. Lawrence Iroquoians living in Stadacona. Specifically, he disagreed with traditions involving unmarried native girls and their preparations for marriage. Introducing the topic, Cartier recorded that "They have another custom bad for their girls; for after they are of age to marry they

$5^{1} \quad$ Lyon, Enterprise of Florida, 149, 170, 176-177.

$5^{2}$ See Devens, "Separate Confrontations", 461-462, 465-466; Slater, “Nought but women", $40-41$. 
are all put into a common house, abandoned to everybody who desires them until they have found their match". Cartier referred to life in France to illustrate his point, adding "And all this we have seen by experience, for we have seen the houses as full of the said girls as is a school of boys in France". ${ }^{53}$ It is difficult to ascertain Cartier's meaning here and his opinion may not have been shared by others on the expedition. Possibly he disagreed with the relative autonomy in the house enjoyed by female Indians. Perhaps he opposed the logic behind the process in terms of orchestrating marriages. He almost certainly saw the housing of native girls in a common location as a gateway to scandalous behaviors (in subsequent sentences of his account he also criticized native participation in "gaming"). Regardless, native women in this situation represented a danger to Cartier. ${ }^{54}$

A much more telling example of how conquistadors believed the actions of indigenous women at times threatened colonial ventures took place in reference to the young girl Cartier had "received" from the Iroquoian leader Donnacona. As noted, relations with the natives of Stadacona steadily worsened as the second French expedition continued its quest to find mineral or agricultural wealth, and a pathway to Asia. In light of these increasing tensions, Donnacona and his advisors increasingly distrusted Cartier, a reality soon known to many in Stadacona. Repeating his practice of presenting small trinkets to the Indians as a means of gaining trade items, the Frenchmen received an unexpected response. According to Cartier, the two sons of Donnacona, prior to their second kidnapping by the French "gave them [the Indians receiving the presents] to understand that what we gave them was worth nothing, and that they should have as many hatchets as knives for that which they gave us". Convinced by these arguments, natives of Stadacona began to protest to Cartier and "wished to take back the three children that the said Donnacona had given to the said captain" previously. According to the French leader's accounts, "in fact, they made the largest of the girls flee from the ship" after which the natives of the town stayed away from the vessels and Frenchmen for several days. ${ }^{55}$

53 Baxter, et al., A Memoir of Jacques Cartier, 177; Cartier, Voyage de J. Cartier, 30. Cook used the word "brothel" to describe the building in his translation. Cartier, et al., The Voyages, 69 .

54 European consternation over native morality, sexuality, and unmarried women persisted after French and Spanish missionaries arrived in the following years. See Jennifer S.H. Brown, "Reading beyond the Missionaries, Dissecting Responses", Ethnohistory 43, no. 4 (1996): 713-719; Devens, "Separate Confrontations", 467-470; Mann, Iroquoian Women, 278-280; Noel, "Revisiting Gender", 60.

55 Baxter, et al., A Memoir of Jacques Cartier, 181; Cartier, Voyage de J. Cartier, n.p; Cartier, et al., The Voyages, 70-71. 
Female natives again served as intercultural relationship barometers to the French. Different from the situations addressed above, however, in this encounter, the role of a native girl reflected the breakdown of accommodation. Faced with male native accusations of unfair exchanges and unhappy Indian neighbors, Cartier focused on the roles played by female natives. As both Indians and Frenchmen attempted to reach common ground over the next few days, the native girl, once a "gift" representing alliance, now an "escapee" representing disharmony, became a bellwether of ongoing diplomacy. Unnerved, Cartier bolstered his fortifications and displayed his contingent's war-making ability by increasing the number of guards manning the watch and sounding trumpets every time the guards changed posts. According to Cartier's accounts, these theatrics led Donnacona and his lieutenants to regret the break with Cartier and, on multiple occasions, to visit the French leader and attempt to defuse tensions. In response, Cartier spurned Donnacona's efforts, pointing out that the native leader had not kept his promises "by having taken back the girl that they had given him, and other ill turns that he named to them". Nevertheless, Cartier agreed to forgive the Indians if they reformed their inhospitable conduct. In the French leader's words, Donnacona and his followers then "thanked the said captain and promised him that they would restore to him the girl that had fled away within three days". But diplomatic machinations continued. Upon the headman initially returning the girl to Cartier, the Frenchmen rejected her, saying that she should return to Stadacona. According to Cartier's accounts, this rejection made Donnacona beg that he change his mind, explaining "that they had not counseled her to go away, but that she had gone away because the cabin-boys had beaten her". He then pleaded for Cartier to once again take her as a gift. Apparently satisfied with Donnacona's explanation and/or contrition, Cartier agreed to take the girl "After which things the captain ordered bread and wine brought and feasted them". ${ }^{56}$

Either through their autonomy in decision making or symbolism in negotiations, to Cartier, female natives shaped the nature of relationships between French and Indians that influenced words and actions of all involved. Though Cartier's debatable interpretations of these events bring into question our understanding of the situation, at least one factor is clear. By Cartier's second voyage to New France, at least some Stadacona Indians challenged the fairness of the French in their exchanging of goods with natives. As a result, the natives temporarily halted interaction with Cartier's expedition to show their unhappiness. The situation regarding the departure of the young girl from Cartier's

56 Baxter, et al., A Memoir of Jacques Cartier, 182-183; Cartier, Voyage de J. Cartier, n.p.: Cartier, et al., The Voyages, 71-72. 
ships is less clear, however. Did the natives of Stadacona arrange her escape as means of punishing Cartier? Did the young girl flee the ship on her own as a means of protesting the French treatment of Stadconans? Or did the young girl depart the ship for reasons that had nothing to do with trade or general French treatment of Indians and simply tried to escape physical brutality at the hands of French boys on the ship? Though the answers are unclear, the situation again depicts the power of native women in this situation.

Spaniards in Florida also focused on female autonomy in negative terms, especially when manifested in actions they perceived as betrayal. As they journeyed through the northern Florida borderlands, De Soto and his men visited the village of "Cutifachiqui", near present-day Augusta, Georgia. On the outskirts of the town Spaniards captured three Indians who informed them "the mistress of the country had already information of the Christians, and was waiting for them in the town". Shortly thereafter, this cacica came out of the town and addressed De Soto, stating, "Be this coming to these your shores most happy.... With sincerest and purest goodwill I tender my person, my lands, my people, and make you these small gifts". She then gave the Spaniards animal skins before "drawing from over her head a large string of pearls", which she placed around De Soto's neck while "exchanging with him many gracious words of friendship and courtesy". The native leader subsequently presented members of the expedition with "many turkeys" and, "observing that the Christians valued pearls", invited the Spaniards to load their horses with as many as they could find in the town. The cacica's initial hospitality confirmed in the conquistadors' minds the wealth that Florida contained. They focused on the gifts she provided, highly regarding the "pearls, of which those who had the most knowledge of their value, said they were very precious". ${ }^{57}$

But the positive impression of the female leader held by the Spanish soon changed. As Spanish demands for food and labor resources from the Indians increased, the cacica expressed to De Soto that she wished his contingent would leave her town. In response, "the Governor ordered that she should be placed under guard" and took her with him as he searched for riches in neighboring lands. Over the next week, the cacica appeared to have changed her mind and helped De Soto recruit porters and laborers for his needs. De Soto relied on her to describe the surrounding lands and lead him to further riches. The cacica had other plans, however. "One day while on the journey" according to the Gentleman of Elvas' accounts "she left the road, with an excuse of going into a thicket, where, deceiving them [De Soto and his men], she so concealed herself that for all their search she could not be found". Not only did she 
flee the Spaniards, she also took back some of the wealth they had previously gained on their journey. In addition to "three slaves", she also "took with her a cane box, like a trunk ... full of unbored pearls, of which, those who had the most knowledge of their value said they were very precious". Though one of the Spaniards convinced two of the "slaves" to again join De Soto's contingent, he could not get the remaining slave or cacica to abandon "their evil design". 58

The issue of women's power in native communities also gained the attention of Champlain almost six decades later. Following Cartier's voyages, and the circulation of his writings and tales throughout France, French regard for the lands he explored worsened. Changing political dynamics in France, the apparent lack of a westward passage to Asia, discovery of few precious metals, a climate unsuitable for widespread agriculture, and uncertainty over the attitudes and actions of native inhabitants in the region limited additional French exploration and colonization ventures. These factors, along with other concerns in Europe, led New France to flounder, or at least, be largely ignored by most people in the home country. Champlain's entrada took place in 1603 and served as the first sizeable French effort to survey the region, hopefully change existing attitudes, and establish a basis for greater rewards in the future. As a bookend to the sixteenth century, impressions of Frenchmen on the expedition reveal much about the durability of attitudes regarding native women.

Champlain did not address female Indians at length in his accounts, especially in comparison to Cartier. ${ }^{59}$ Yet on the occasions he did mention them, Champlain too focused on women's influence over native society, and thus in part, men. At one point in his 1603 account, Champlain described the marriage customs of Indians he encountered in New France, though it is unclear if he is referring to Innu or Iroquoian peoples. Opening his description, the French explorer recorded "that when a girl is 14 or 15 years old, she will have many suitors and male friends, and will keep company with all those who suit her. Then, at the end of some five or six years, she will take whichever one she pleases for her husband". After explaining men were free to dissolve the union if the marriage did not produce children, he observed that "the girls are more free than

58 Ibid., 1: 69-72.

59 In contrast to Cartier, Champlain has been identified by scholars as "generally interested in others and comfortable with their diversity". In addition, he "belonged to several circles of French humanists" and interacted with various native leaders whom he regarded "with respect and affection”. David Hackett Fischer, Champlain's Dream (New York: Simon \& Schuster, 2008), 527-530. Also see Marcel Trudel, "CHAMPLAIN, SAMUEL DE", in Dictionary of Canadian Biography, vol. 1, (University of Toronto/Université Laval, 2003), http:// www.biographi.ca/en/bio/champlain_samuel_de_1E.html. (accessed January 3, 2016). 
the women". Champlain proceeded to explain male-female relationships in marriage: "Now as soon as they are married [the women] are chaste, and their husbands are, for the most part, jealous, who gives presents to the father or relatives of the girl whom they have married".60

For Champlain, women were problematic in native society. Young women apparently had freedom to interact with men of their choosing and dictate their marriage partner. While men may dissolve a childless marriage, the marriage itself produced jealousy in men and obligated some type of wealth transfer from the husband to the wife's family. ${ }^{61}$ These views are commonly found in descriptions of marriages in all cultures at all times. They also may have been influenced by Cartier's tales from earlier in the sixteenth century. Indeed, issued in relation to the previous French accounts of native women in New France, they had greater meaning; the behavior of women can produce disruptions that are disadvantageous to men.

Spanish descriptions of the Florida Guale Revolt of 1597 further illustrate this mindset and demonstrate how in the opinion of European explorers, native women could threaten settlement endeavors, irrespective of the roles they played. The primary account of the event, written by Father Luis Jerónimo de Oré, a Jesuit missionary, blamed the Indians' depraved customs for initiating the revolt and focused on the role of women. According to the chronicler's description, an Indian man who missionaries believed had been converted to Christianity took offense when a priest told him he could no longer have more than one wife. After killing the offensive friar, the man and other male Guales "began to exchange women in order to give rein to their sensuality and unlawful pleasures". They ultimately killed five missionaries, destroyed many missions in the region, and defied Spanish attempts to quell the uprising for several months. No evidence indicates that native women instigated the Guale Revolt of 1597, which took place for many reasons. ${ }^{62}$ But according to Father Oré's account, their presence and participation in lascivious activities motivated male natives to reject Spanish control and violently rebel. Similar to Cartier

\footnotetext{
6o Heidenreich and Ritch, Samuel de Champlain before 1604, 284-285.

61 For information on Iroquois marriage practices from a comparative perspective, see Brown, "Economic Organization", 155-156.

62 Other possible reasons for the revolt include native resistance to Spanish tribute demands, missionary restriction of native movement between villages, priest interference in traditional leadership structures, and Guale understandings of polygamy in terms of households and gender. See Paul E. Hoffman, Florida's Frontiers (Bloomington: Indiana University Press, 2002), 82-83; and Sarah M.S. Pearsall, "'Having Many Wives' in Two American Rebellions: The Politics of Households and the Radically Conservative", American Historical Review 118, no. 4 (October 2013): 1001-1028.
} 
in New France, the Spanish missionary in Florida characterized the presence of native women he deemed to be immoral as problematic for colonial designs.

These examples indicate that sixteenth-century European explorers in Florida not only blamed native women for actual and potential problems they faced but also vilified them for their literal presence and figurative role in North America. Champlain offered another negative assessment of native women in this regard, though in a context not yet seen in his writings or those of Cartier, De Soto, or Oré. Shortly before returning to France in late 1603, Champlain recorded a tale he had heard from local Indians in New France, probably Innu, about a dangerous creature known as "Gougou" that lived in the region. Significantly, this creature resembled a woman. Champlain described the creature in detail:

and they told me it had the shape of a woman, but most terrifying and of such a size that, according to them, the top of the masts of our ship would not have come up to its waist, so big do they depict it. And they said that it has often devoured and does yet devour many Sauvages, whom it puts into a great pocket when it can catch them, and then eats them. And those who had escaped the perils of this miserable beast said that its pocket was so big that it could have put our ship into it. This monster, which the Sauvages call Gougou, makes horrible noises in this island, and when they speak of it, it is only with a strange terror that no more can be said;

European explorers of North America commonly noted native descriptions of fantastical creatures living in surrounding lands. Often these explorers trivialized such tales and used them as evidence of native barbarism or paganism. ${ }^{63}$ Champlain did not conform to this pattern. He believed that Gougou existed, stating, "And what makes me believe what they say is the fact that all the Sauvages in general fear it, and speak of it so strangely that if I were to put down everything that they say about it, it would be taken for lies; but I hold that this may be the haunt of some Devil which torments them in this way".64

Most Europeans who heard this tale rejected its veracity. The French conquistadors on this expedition, and others before it, failed to acknowledge

63 For an alternate explanation of native stories featuring supernatural creatures and how European colonists interpreted them, see Cameron B. Strang, "Indian Storytelling, Scientific Knowledge and Power in the Florida Borderlands", William and Mary Quarterly 70, no. 4 (October 2013): 671-700.

64 Heidenreich and Ritch, Samuel de Champlain before 1604, 360-363. 
such native "keepings" and other oral tales that often had spiritual or ethical meanings for the Indians themselves. ${ }^{65}$ Yet as a metaphor, it may have revealed much about the natives encountered by French explorers, or the mindset of Champlain himself. Descriptions of Gougou in some ways mirrored European conquistadors' general views of the travails they faced in exploring their New World. Death and disaster at the hands of unknown or misunderstood North American phenomena frequently occurred. Conquistadors repeatedly encountered both mundane and mysterious "devils" that tormented them on their travels. And as noted, French explorers experiencing difficulties in dealing with the natives of New France at times focused on the role of women when explaining their misfortunes. Of all the extraordinary characteristics supposedly manifested by Gougou, perhaps the most believable to Champlain and his followers was that it "had the shape of a woman".

\section{Conclusion}

Despite their many differences related to colonial motivations, goals, and activities, French conquistadors in New France and Spanish conquistadors in Florida viewed and treated native women in similar ways. As J.H. Elliott has alluded in reference to English and Spanish colonization efforts overall in the Americas, for European men encountering peoples and situations that frequently proved difficult to navigate, "Differences of creed and of national origin paled before the universality of experience".66 Perceptions of their experiences led conquistadors to believe that female Indians represented intercultural guideposts in their navigation of North America's borderlands and pursuit of profitable endeavors. Native women served as signs of welcome, facilitators of diplomacy, saviors of European lives, and warnings of hostility from native communities. Even when female Indians did not live up to the ideals of French and Spanish explorers, they functioned as outlets of frustration, scapegoats, and reminders of potential dangers to colonial enterprises overall. In these capacities, native women provided links between North America's northern and southern Atlantic borderlands that deserve greater study.

Unfortunately for French and Spanish conquistadors in this setting, their understanding of native women was flawed. Both groups trivialized women's actions and refused to acknowledge their autonomy in acting the way they did.

\footnotetext{
65 Mann, Iroquoian Women, 29-30, 60.

66 John H. Elliott, Empires of the Atlantic World: Britain and Spain in America 1492-1830 (New Haven, CT: Yale University Press, 2006), xiii.
} 
Female Indians' expressions of happiness or discontent received little analysis or contemplation in explorers' accounts and were generally taken at face value. Accordingly, French and Spanish conquistadors missed several clues as to the substantive role native women often played in orchestrating Indian communities' strategies toward European invaders. These missed clues and misunderstandings would persist and intensify as colonization of North America increased in later years. Colonial powers continued to misinterpret and marginalize native women along the "coast of Florida", for centuries, much like they misunderstood native peoples in general, with long-term consequences for all involved. 